\title{
Corporate Social Responsibility in the Niger Delta Region of Nigeria: In Who's Interest?
}

\author{
Rebecca Enuoh ${ }^{1} \&$ Sunday Eneh $^{2}$ \\ ${ }^{1}$ Faculty of Management and Law, University of Bradford, West Yorkshire, UK \\ ${ }^{2}$ Department of Business Management, University of Calabar, Nigeria \\ Correspondence: Rebecca Enuoh, Faculty of Management and Law, University of Bradford, BD9 4JL Bradford, \\ West Yorkshire, UK. E-mail: roenuoh@bradford.ac.uk or rebenuoh@yahoo.com
}

Received: July 25, 2015 Accepted: August 21, 2015 Online Published: August 28, 2015

doi:10.5539/jms.v5n3p74 URL: http://dx.doi.org/10.5539/jms.v5n3p74

\begin{abstract}
Business organizations are expected to meet certain social obligations in terms of corporate social responsibility (CSR). In the Niger Delta region of Nigeria oil Multinational corporations (MNC) have not been left out in this regards. There have been remarkable changes in the host communities as most of the facilities provided by the MNCs have either been absent, insufficient or dysfunctional. Despite the activities of the MNCs, the opinion and attitudes of the host communities portray an act of antagonism rather than support for the MNCs giving rise to an imaginary gap between what is done and how it is perceived. The questions then are; what could be responsible for such attitude? And in whose interest is CSR by the MNCs. This paper examines the host communities' perception of CSR initiatives by the MNCs. The study is based on analysis of in-depth semi-structured interviews and focus group discussions with the host communities in the empirical section, as well as a review of related literature. From the stakeholder perspective, this paper argues that the practical difficulty encountered by the MNCs in achieving the desired outcome from CSR programs is due to lack of understanding and consideration of the contractual relationship between the host communities and the MNCs. The results show that the stakeholders' perspective deserves huge attention for those MNCs considering the keys to business success. The paper concludes that CSR initiatives cannot be successful without proper need assessment from the affected stakeholders whose interest ought to be protected. This paper contributes to a proactive rather than a reactive approach to CSR initiatives.
\end{abstract}

Keywords: corporate social responsibility, Niger Delta region, stakeholder theory, multinational corporations

\section{Introduction}

One of the major challenges of most corporations is how to achieve integrity and trust from its stakeholders. Meeting the expectations of its shareholders as well as the interest of the stakeholders has been a contested issue for most corporations because of their conflicting prospects. Due to the dependency of business on society, certain responsibilities or obligations are imposed on the business organizations to discharge as part of their CSR (Inyang, 2013). Despite the increased attention given to the issue of CSR, choosing the right form of CSR and successfully implementing same has been a difficult task. This difficulty is often associated with diversified interest of the parties involved. In the Niger Delta region of Nigeria, multinational enterprises are expected to offer social services and welfare programmes as part of their CSR initiatives as they pursue their normal activities. These expectations are not far-fetched as MNCs are now committed to funding community development programmes by way of providing education, scholarship, and road construction (Frynas, 2005). The community development initiative in the Niger Delta is widely criticized by the host communities due to the fact that adequate attention is not directed at tackling the problems that the multinational enterprises accepted to resolve (Frynas, 2005). Therefore, CSR does not seem to be a usable tool to alleviate poverty and other developmental goals as originally envisaged. However it is argued that CSR approaches by MNCs do not justify such claims (Blowfield \& Frynas, 2005). While the MNCs are publicizing their role in the transformation of this region, the host communities feel otherwise.

The general expectations of the people of the Niger Delta region is seeking employment for the youths, reduction in environmental damage to their farmlands (livelihoods), and economic and social development of the entire region. To the host communities, these expectations have not been met which has resulted in a conflicting 
relationship with the MNCs. In the Niger Delta region, the root cause of hostility between the oil companies and host communities is also linked to the inherent discontent with the governance system of Nigeria. The government is perceived to support the MNCs operation at the expense of the host communities. In addition, the chosen approach to remedy the problems, which has been to provide some basic infrastructural facilities for the communities does not seem to tackle the main issues confronting the region. Therefore, what is being witnessed is the neglect of the role of CSR in improving the living standards of the people and sustaining the livelihoods of the communities. It seems therefore that the CSR initiatives are in the interest of the MNCs who are indirectly sourcing for a conducive environment to maximize their earnings and to be seen as being socially responsible (Eweje, 2006).

The aim of this paper is to explore the inclusion of stakeholder's perspective in CSR and the extent to which the host communities' interest on CSR is needful for harmony between the oil companies and people of the Niger Delta region. The article begins with a conceptual analysis of CSR that appears in academic literature and the issue of CSR in the Niger Delta region of Nigeria. This is followed by the interest of the host communities in CSR as well as that of the oil multinationals. The section that follows considers the host communities as stakeholders and the study area and methodology used for the research. After which the major findings from the interviews with the host communities as well as the focus group discussions are analyzed to explain the perception and expectations of the oil industry. This is followed by the concluding section.

\section{Conceptual Analysis of Corporate Social Responsibility}

Corporate Social Responsibility (CSR) is a concept that has undergone several academic debates for over five decades. There is no agreed definition of CSR due to its multi-disciplinary nature giving rise to multiple conceptualizations (Garriga \& Mele, 2004). There have been continuous arguments about its meaning, approaches and even the terminologies used to explain why businesses should see beyond making profit. Therefore, having an acceptable definition for it is uncertain as different countries, local and multinational corporations are gradually engaging in activities in pursuit of social development. CSR is an obligatory move by MNCs to address the challenges in the society, technologically and financially, in order to benefits the society at large. CSR compels organizations to consider societal interest and accept responsibility to positively influence the communities and other stakeholders in its operation (Ako, Obokoh, \& Okonmah, 2009). Amao (2008) defines CSR as comprising of labour right, bribery and corruption, human right, transparency, consumer protection, and disclosure of information. This definition explains the level of ambiguity of the concept.

CSR is an approach which aims at helping organizations implement voluntary obligation to support and solve social issues and to fulfill commitment. CSR as a management concept helps companies to incorporate social and environmental concerns in their business operations and relations with their stakeholders (Freeman, 1998). It has become a method used by organization to achieve a stability of economic, environmental and social imperatives, with strong concern in addressing the aspirations of shareholders and stakeholders (UNIDO, 2007). The definition of CSR has ranged from simplistic to complex with diverse associated terms and ideas which often are used interchangeably including corporate sustainability, corporate citizenship, corporate social investment, the triple bottom line, socially responsible investment, business sustainability and corporate governance (Thomas \& Nowak, 2006).

In today's dynamic environment, Orlitzky (2007) sees CSR as the universal remedy for solving the global poverty gap, social exclusion and environmental degradation. Weltweit, (2008) opines that CSR is a business commitment to manage and improve the environmental, social and economic implications of the activities of the organization. Hohen (2007) supports that CSR is the task of a firm or multinational organization to channel the decisions of an organization to impacts the environment through transparent decisions toward the development and sustainability of the society while taking into cognizance the expectation of stakeholders whether it is in line with existing law and with stipulated norms of behavior in the organization. CSR is a commitment by organization to act ethically, promotes economic development, improve quality of life of the workers, their families, local communities and the society (WBCSD, 2001).

From the array of definitions by scholars and researchers, it is obvious that CSR is characterized by the decisions to improve the environmental degradation, social and economic activities of its existence. On the other hand, CSR is a strategic tool of achieving profitability and also helps the organizations to enhance corporate values while achieving a stable and long-term growth for the shareholders. Multinational corporations are driven by this approach to connect the environment, socially and economically as part of their value and culture, decision making strategy and operations to create wealth and enhance the society. This idea is what is considered in the next section on the Niger Delta region of Nigeria. 


\section{Issues on CSR in the Niger Delta}

The Niger Delta region has been faced with several issues as regards the CSR activities by the multinationals operating there. The reliance by the government and oil communities in Niger Delta on MNCs is as a result of inability to encourage social and economic development in the Niger Delta (Ite, 2004). An enabling environment is found to be an issue for CSR in Niger Delta and this has affected Shell contribution to the development of the region (Fox et al., 2002). This issue is closely related to a policy of the environment that ensures that business functions reduce environmental social cost and impacts and also maintains economic gains. The public sector roles imply that both MNCs and CSR require enabling environment for their smooth operation (Ite, 2004). But the lack of this enabling environment for CSR in Nigeria is an indication that of some level of ineffectiveness with limited level of significance and political support.

The conflict in Niger Delta is multidimensional and the possibility of achieving the needed result is limited. Though, the conceptual linkage to conflict reduction in Niger Delta is based on the assumption that CSR initiative that contributes to sustainable community development will address local grievances and improve livelihood (Idemudia, 2009). This does not seem to be the reality on ground. It is obvious that the level of violence in the Niger Delta is alarming, the result to the community members is that lack of employment opportunity, and environmental degradation are the root cause of conflict in the region. The responsibility of government is crucial in CSR development and maturation in Nigeria. Idemudia and Ite (2006) posit that CSR may help in shaping an institutional environment that foster sustainable economic growth.

However, the pursuit of an active distributional and social policy or the provision of motivation for ecological behavior, the critical issue on CSR is the absent of enabling environment. This is due to undermining tendencies of CSR initiative which reduce the positive impact of CSR. The reality is that corporate efforts are not used in meeting the community demands in the face of huge amount of community expectations that are not met due to government failure to meet its fair share of responsibility. Hence, this is a true reflection of situation in the Niger Delta region. These may be due to the variance in interests and expectations associated with the CSR activities.

\section{Host Community Interest in CSR in Niger Delta}

There are high expectations by host communities that CSR should be of immense impact to the development of Niger Delta region. These expectations vary from one community to another. The need to identify the community expectations is necessary to align the corporate expectations of the MNCs in order to sustain the psychological contract between the host communities and the oil companies, and since the community expectations are found to influence the decisions of the community, it is expected that adequate examination of the forces that drive the community expectations will aid in remedying recurrent problem of community expectations (Idemudia, 2007). It is believed that the implementation of CSR in these communities would reposition the livelihood of the entire region. Idemudia (2007) also states that there is a considerable low support among host communities and oil companies in donating fund compared to other community expectations. The perception of host communities is that MNCs should be more responsible for development, but the MNCs see the government as playing a principal role in the development of the communities. This is argued that such perception has made the multinational companies to lose their legitimacy with the communities thus making the companies subject to criticism.

Evuleocha (2005) stresses that Niger Delta will rely on the government in negotiating acceptable terms of production with the oil producing communities such as environmental compensation for damages, decisionmaking involvement in oil production, rule of law, transparency and accountable administration of the money from oil revenue. The researcher further maintains that people in Niger Delta region are able to make their demands and grievances known to the oil companies and to government based on their ability to exercise the fundamental human right without reprisal from the security forces. Oil companies as part of their long term interest is to promote good relations with the communities in the Niger Delta region. This involves compliance with environmental laws and international standards in development to ensure their presence does not aggravate conflict. Also with intervention in areas considered political for decision to be taken, the interest of the host community on CSR is needful. Afinotan and Ojakorotu (2009) emphasize that the prospects of conflict resolving in the Niger Delta region depends on dialogue and negotiation.

A study by Ojo (2012) indicates that CSR is not benefiting the host communities as it ought to. The effort made by government to end ecological devastation in the Niger Delta region is established to regulate the petroleum industry in order to improve the situation. Nigerian National Petroleum Corporation (NNPC) and Department of Petroleum Resources (DRR) have power to impose and exercise political will to regulate the oil sector. CSR is therefore needed to address host communities perceived needs and poverty reduction. CSR has brought about 
amnesty to the Niger Delta region, oil companies have allocated fund to the amnesty programme as part of CSR. Facts have shown that oil companies and government have settled the leaders of the ex-militants to keep them off from destroying oil facilities (Oteh \& Eze, 2012). Though amnesty is considered as an effort to buy shortterm cease fires, with little of government commitment to resolve core issues (Nwesom, 2011), the problems of community development have not been addressed and amnesty has become a liability to the CSR in the region. Hence, the common aim of poverty reduction, security and environmental healthcare yet to be achieved through amnesty and CSR initiative in the region. Therefore there is need to consider the interest of the MNC in CSR.

\section{Oil Companies Interest in CSR in Niger Delta}

Multinational corporations all over the world are gradually becoming interested in CSR. There is rising need for companies to offer community development initiative to host communities where the oil companies carry out their operations. The lapses of government to provide adequate infrastructures to the community have put corporations especially the MNCs that operate in oil communities under pressure (Olanrewaju, 2014). The existence of oil exploration in Niger Delta has affected the traditional livelihood of the communities which renders the residents unemployed. The pollution of the waters and the fertile land are affected by the oil spill and gas flaring. It is argued that oil companies should take account of the social, ethical, and environmental perspectives of their operations (Olanrewaju, 2014). The principle of CSR theory assumes that business has a duty in the host community beside its obligation to the shareholders of the corporation. It evidenced that for businesses to grow, they must carry out their function in ways that add value instead of detracting from the economic and social infrastructure of the host communities.

CSR is acknowledged as a way a corporation can incorporate the social and environmental issues into the operations and relations with the public. It is therefore pertinent that business must contribute to society in a way that is socially responsible (Inyang, 2013). CSR has a voluntary responsibility to business community to ensure sustainability of the social environment. Therefore, a corporation must establish a positive environment for its operation to continue. It is obvious that businesses engage in social investment to achieve competitive advantage against rival with less social development to reduce cost and maximize their market share (Frynas, 2005). CSR is relevant in helping multinational organization obtain social license to operate in societies (Hohnen \& Potts, 2007). CSR requires comprehensive policies and practices to drive social development in an ethically and legally manner to improve the society. Though there are challenges to accept the onerous task of social responsibility in oil communities, but this is with some level of advantage for the survival of the oil companies.

The CSR of oil companies is established against the ideology of profit first of multinational oil business (Ojo, 2012). The kin interest of oil companies to undertake community development is based on conception that operates at the level of the market that corporations should be free to act solely on the basis of profitability without regard to national or local consequences. Maximizing profit is noted to be the only reason that companies exist and expenditures are resisted when found to be beyond what is expected (Ashton-Jones, 1998). Though, CSR is a means of paying back of the community, the use of philanthropy has become the basis of implementing community development in oil communities. Shell as one of the multinational oil companies has combined its CRS investment with its business goal to improve the negative environment. It is noted that a company survival and the level of business success significantly depends on the improvement of the communities (Ojo, 2012). The improvement of lives in the region have made oil companies such as Total, ExxonMobil and Shell to invest millions of dollars in social projects for communities and this has a close competition with government commitment in the region (Total, 2011; Shell, 2007).

Oil and gas transnational corporations such as Shell, Chevron, Texaco, Exxon Mobil, Total, Final Elf, Agip etc. have keen interest in CSR. These companies have contributed to growth of Nigeria economy and to the communities the corporations carry out their operations (Abubakri et al., 2014). For instance, the development of education, scholarship, provision of equipment, health, agriculture, granting of micro-credit schemes to farmers, etc. are various areas that transnational corporations have exhibited CSR. This is confirmed by Eweje (2006) stating that these corporations are performing well in respect of community development. It is worth noting that in today dynamic environment CSR strategies are of enormous benefit not just for the host communities but also to the MNCs. Hence, CSR has become a rational economic decision-making for the development of diverse communities (Idemudia, 2009).

Abubakri et al. (2014) opine that effective CSR has the potential of ensuring that corporation adopts community relations. Therefore, viable community relation is needful by transnational corporation as part of their CSR initiative for enhance social and developmental programmes. In addition, the interest of oil corporations in Niger Delta in CSR has been a questionable approach with the host community for enduring peace. Though amnesty is 
partial means of sustaining peace between the corporation and the oil community; CSR if effectively implemented become a strategic solution to a win-win relations in the region. It is therefore important that the interest of the MNC as well as that of the host communities should have a meeting point. This cannot be achieved without the MNCs acknowledging that the host communities have a stake in their operations and therefore deserve adequate attention and due consideration.

\section{The Host Communities as Stakeholders}

The perspective of this study is similar to the stakeholder approach by Edward Freemen. This approach examines the other important stakeholder groups that businesses have to be responsible to. Freeman (2004) opines that the stakeholders should be able to contribute to the direction of the firm in which they hold a stake. Those groups who have a stake in the firm include: customers, shareholders, suppliers, employees and the local community (Garriga \& Melé, 2004). With the array of stakeholders that require attention and commitment of the firm, the firm is faced with the challenge of where attention should be focused. Though there have been arguments as regards which stakeholders should be treated as being more important than the other, it could be said that different firms face different challenges in this regards, hence the level of importance of the stakeholders depend greatly on the industry.

The situation in the Niger delta has put the host communities at the forefront of the affairs of the oil companies. The oil industry in Nigeria has come under increasing pressure from its stakeholders to act responsibly and to engage effectively with stakeholders through dialogue and practices. Local communities as know stakeholders cannot be ignored. The importance of stakeholder engagement in CSR practices need no emphasis as the situation of incessant conflicts and disagreement between the MNC and the host communities buttress the fact that the MNC cannot operate in isolation. No matter the array of groups and individuals that claim to have a stake in the affairs of the oil companies, the local communities seem to directly affect their operations. The stakeholder perspective therefore forms the theoretical framework of this research.

\section{The Study Area and Methodology}

The Niger Delta region is mainly inhabited by minority ethnic groups such as Ijaws, Istekiris, Urhobos, Ibibios and Edos. This region extends over an area of about 70,000 square kilometres, which amounts to about 7.5 per cent of Nigeria's total landmass (Idemudia, 2007). The coastline extends for 560 kilometres, roughly two-thirds of the entire coastline of Nigeria. The region has a population of 27 million people, of which 75 per cent live in rural areas (Commission(NDDC), 2004). The Niger Delta region consists of nine of Nigeria's 36 states, which includes; Abia, Akwa-Ibom, Bayelsa, Cross River, Delta, Edo, Imo, Ondo and Rivers states (see figure 1). Oil was discovered in 1956 by Shell in Oloibiri field (Ajibade \& Awomuti, 2009). The commercial exploitation of oil began in 1957. Oil exploration and exploitation has developed to become the largest business sector in the country with increasing revenue of about US $\$ 340$ billion in 2006. Oil accounts for 98 per cent of exports earnings, over 80 per cent of government's annual revenue and 70 per cent of budgetary expenditure (Udeh, 2002). This therefore explains the extent to which the Nigerian government/economy depends on crude oil (Ako et al., 2009).

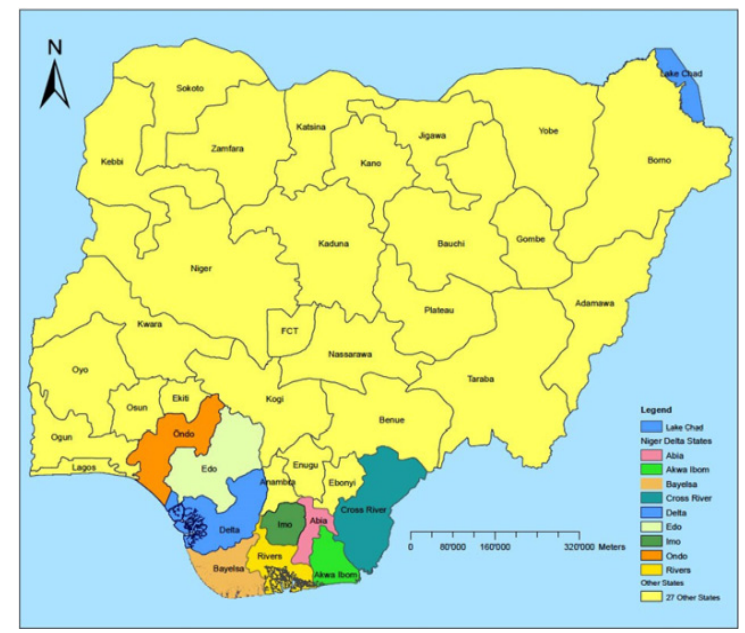

Figure 1. Map of Nigeria showing the Niger Delta state 
The industry is operated mainly by oil-multinationals with the federal government holding majority equity stakes in them through its national oil company, the Nigerian National Petroleum Corporation (Ako et al., 2009). Most of the oil exploration and production activities take place in the Niger Delta region. The Nigeria Investment Promotion Commission reports that crude oil production in the first quarter of the year 2014 rose to an average of 2.26 million barrels per day, Nigeria ranks as Africa's largest producer of oil and the thirteenth largest oil producing country in the world. It also states that the major international oil companies (IOC), which are presently represented in Nigeria, are Total, Chevron, ExxonMobil, Elf, Shell, ConocoPhillips and Eni. These oil multinationals operate both onshore and off-shore.

The selected state for this study is Akwa Ibom. The state is made up of 31 local government areas (see figure 2). It comprises several related sub-ethnic groups which include; Ibibio, Annang, Oron, Eket, Ibeno, Mbo, Okobo and the Andonis. The population of the State is 3.9 million people (2006 Census) with average population density of 463 inhabitants per square kilometre. Majority of Akwa Ibom oil is explored offshore. The site of oil production determines the extent to which community protest can negatively affect oil production and facilities and how environmental degradation due to oil exploitation negatively impacts on the host communities (Idemudia, 2007). However, both onshore and off-shore oil productions do cause considerable environmental damage.

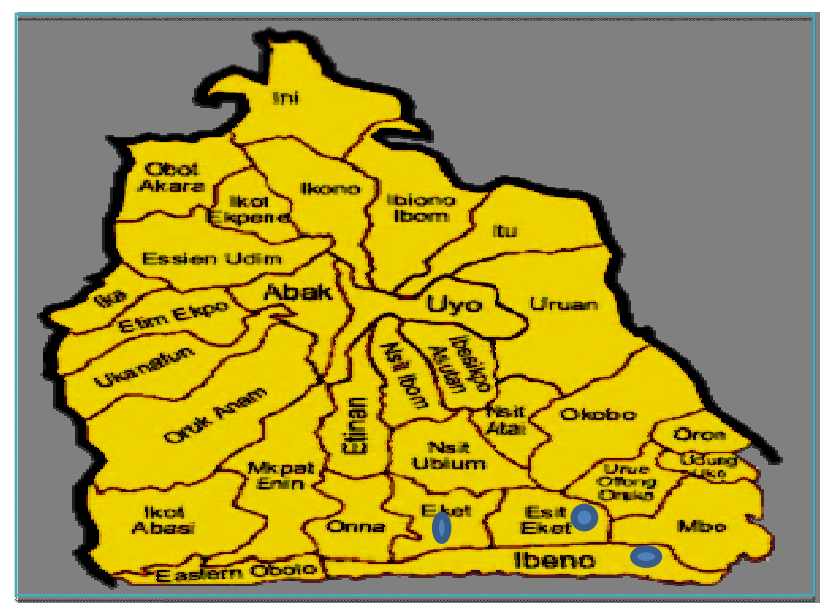

Figure 2. Map of Akwa Ibom state indicating location of study area

Source: https://www.google.co.uk/url

This is an exploratory case study research aimed at clarifying the relationship and perceptions of the host communities and the MNCs with regards to their CSR activities. Saunders et al. (2009) posits that exploratory studies are aimed at finding out and clarification of the nature of a phenomenon. This can be achieved through conducting interviews (Saunders et al., 2009). Based on the differences in opinion and view-points, case studies could be used to evaluate the perspective of the different actors (Yin, 1994). The case-study research enables one to have a holistic view of the situation rather than being based on isolated factors (Yin, 1994). Both primary and secondary data were used for the study. Semi-structured interviews as well as focus group discussions were used as primary sources. The primary data collected for this article were in the coastal host communities of ExxonMobil in Akwa Ibom State within three host communities. These communities include; Edo, Mkpanak and Eket communities in EsitEket, Ibeno and Eket Local Government Areas respectively. The villages were selected based on recognition as host communities, geographic proximity with respect to oil exploration and the presence of multinational oil company offices. All the communities selected were involved in farming, fishing and trading as sources of livelihood.

Participants for the study included chiefs, local politicians, women, and youth leaders that have privileged information due to either their position and/or have been directly involved in negotiation with oil MNCs on behalf of the communities. The focus group discussions were held in the host communities. Three focus groups were conducted; one of the focus groups comprised youth only while the other two were a mixture of youth, elderly men and women. The semi-structured interviews involved 24 members of the host communities and 3 employees of ExxonMobil. Purposive and snowballing sampling strategy was used to identify and recruit participants for the study. Most of the participants were selected based on their direct involvement in dealing 
with the MNC on behalf of the communities by virtue of their position in the community. The interviews were arranged and agreed by identified participants. The consent of the participants were sought to have the interviews audio tape-recorded. The interviews were fully transcribed by the researchers and notes taken on the field. The data was analyzed using thematic content analysis for the interviews and debriefing for the focus group discussions.

\section{Community Expectation/ Perception of the Oil Industry}

In line with socio-economic practices in oil producing communities all over the world, the discovery and exploitations of oil has always been a welcome idea for the natives of such communities (Afinotan \& Ojakorotu, 2009). It is therefore not strange that the people of the Niger Delta region were full of hope and excitement that they would legitimately and inevitably be entitled to benefits that come with being oil producing communities. Members of the host communities are of the view that the advent of the MNCs would improve their living standards, provide the needed social amenities and create job opportunities for its indigenes. This assertion is made by a participant from Eket community as follows:

... Actually when we had them at the initial time, we were always happy because we knew that now that we have oil companies operating in our community we'll start benefitting. For instance, we will have job opportunities and other developmental projects like other parts of the world (FG. $17^{\text {th }} \mathrm{Sept}$, 2014. Eket)

It is important to note from the statement above that the idea of the host communities on the expected outcome of oil exploitation on their land is in line with global expectation. There is an indication that the host communities were full of high expectations from the MNCs. The similarities across the researched communities suggest that most respondents in the three villages seem to share a common expectation for infrastructural development, capacity building and poverty reduction. An analysis of the focus groups also buttresses the fact that the immediate communities to the MNCs should be their focal area before considering the benefits to other non-host communities. This affirms the idea of Afinotan and Ojakorotu (2009) who opine that the oil producing communities expect that more people would have the opportunity of gainful employment as oil companies carry out their operations and implement their corporate social responsibility programmes. The participants from the host communities are of the view that the CSR programmes and activities of the MNCs should be part of their contribution to development as well as reduce poverty in the community. This is stated by one respondent, Kingsley of Mkpanak community as follows:

...I don't expect them to give me a car, they have to provide the basic needs [..]. If you take some time and drive around this community you will find out that most people are very poor [..]. I can count the number of people who can afford a meal [..] That is not how it is supposed to be [..] So what's the development there? We are not happy about this. We expect ExxonMobil to create jobs for our people (KA, $17^{\text {th }}$ Oct, 2014. Mkpanak)

This assertion gives an idea of the level of poverty in this community and how the community feels about it. Though the issue of poverty and unemployment is not peculiar to this region, the host communities feel this should not be the case in an oil rich area that should benefit from oil MNCs. It is also believed that oil discovery has brought hope that civilized and modern infrastructure such as electricity, pipe borne water, schools, good roads, well-equipped hospitals, better and more modern fishing equipment and other social benefits will become part of their communities as compared to the rest of the country. They do not expect to be poor in the midst of rich natural resources. The exploration and exploitation of oil in their land means an end to hardship and alleviation of poverty. The participants feel that the MNC have an obligation to catering for the needs of their immediate communities through the provision of basic infrastructural facilities and job creation. These expectations are closely related to the implicit contractual relationship perceived to exist between the host communities and the MNC.

In meeting the expectations of the host communities as well as engaging in CSR, ExxonMobil has carried out several CSR activities. Mobil Producing Nigeria Unlimited (MPN) through the joint venture with Nigerian National Petroleum Corporation (NNPC/MPN) had undertaken several CSR projects ranging from road construction to provision of potable water and electricity, environmental protection activities, upgrading of educational and health facilities as well as support to professions and civil society groups (Mbat et al., 2013). They also affirm that Mobil Producing Nigeria Unlimited corporate responsibility in Akwa Ibom State started from 1980s. With the merger of Mobil and Exxon now giving rise to what is called ExxonMobil in 1997, the CSR projects have taken a different dimension; a shift from the development of infrastructure to human capacity building (Mbat et al., 2013). Over the years, ExxonMobil has done a great job of a good corporate citizen 
through its involvement in CSR activities like school buildings, science laboratories, dormitories, water and electricity projects, hospitals, small and medium scale business support, scholarship scheme programmes and other positive contributions to improve the living standards of the host communities (Ibok \& Mboho, 2011). There is no doubt that these projects and programmes may have benefitted members of the host communities and other neighbouring communities alike.

Despite the implementation of CSR initiatives by ExxonMobil, the company is always in conflict with its stakeholders (host communities) (Michael et al., 2015). This indicates that there is a difference between what is done by the MNCs and how it is perceived. Idemudia (2007) opines that community perceptions often form the basis for community actions to either support or disrupt corporate activities. The actions of the host communities portray an act of antagonism rather than support for the MNCs which have resulted in persistent conflicts. Idemudia and Ite (2006) have identified what they regard as the root and trigger causes of the Niger Delta conflict. They assert that the root causes include political and economic factors while the trigger causes are environmental and social factors. The interconnection between the economic and environmental issues to the conflict relates to the role of poverty, the natural features of oil and the economic impact of environmental degradation on host communities (Idemudia \& Ite, 2006). These and other factors have contributed to the negative perception of the MNCs by the host communities.

Thepossible explanation for the negative perception of the oil industry is a feeling among host community members that the MNCs are only carrying out their CSR programmes for selfish motives rather than protecting their interests. They argue that what ExxonMobil is doing in their community is not bad, but it is based on enlightened self-interest. The participants claim that the activities of ExxonMobil are not based on what the community needs but those things that would improve their social status. A participant from Eket community states that:

\begin{abstract}
If they construct roads, they construct for their workers to drive. How many people outside (company) workers have cars in Eket. They construct for themselves. When you talk about social responsibilities ehmm and you apply the doctrine of enlightened self-interest, whatever you are doing is directly or indirectly for yourself. The company if they apply that doctrine then it is directly doing it for itself, it's not for anybody. Majority of (company), workers, they have 3-4 cars, they drive it on the road and so most of the road constructed is for their workers. If they fail to construct it is also for their workers (PE, $18^{\text {th }}$ Sept, 2014, Eket)
\end{abstract}

However, in the focus group discussion in Mkpanak and Edo communities the respondents were of the view that most of the projects claimed to be executed by ExxonMobil were those done over ten years ago when the company was still called Mobil Producing Nigeria Unlimited. Hence, no new projects have been embarked on in the name of ExxonMobil. They claim that ExxonMobil has an unfriendly attitude towards their host communities to the extent of throwing away all written requests from the host communities into the trash can. It can therefore be argued firstly, that host communities' developmental expectations have largely been unmet and secondly that the level of community participation on the CSR initiatives of ExxonMobil could be a contributory factor to their dissatisfaction. This explains the important role of the host communities in the successful operation of the oil MNCs in providing a peaceful working environment and the need for effective management of CSR activities (Enuoh \& Inyang, 2014). Failure to accommodate the interest of the host communities could result to failure to peaceful coexistence.

It could be argued that the CSR by MNCs have not been effectively managed. There is no doubt that the interest of the host communities as well as that of the MNCs differ in terms of their expectations from CSR activities. While the MNCs are pursuing the goal of peaceful coexistence for their continued operations the host communities expect more commitment in the provision of infrastructures that directly benefit them. The need assessment and dialogue with the host communities could be seen as the missing link that could be explored to achieve maximum results. If the MNC have to protect the interests of the host communities in the pursuit of their goals, then their inputs have to be sought. Planning and implementing CSR projects without the input of the host communities is negatively viewed as a way of boosting the image of the MNCs rather than trying to solve the problems of the communities where they operate. CSR programmes and initiatives need to be viewed from a proactive point of view in order to achieve the desired win-win outcome for both the benefactor and the beneficiaries.

\title{
9. Conclusion
}

In the planning, design and implementation of CSR programmes and activities, there is need to consider the needs of both parties for mutual benefit. This will enable oil MNCs to derive maximum benefits from their CSR 
initiatives, be less prone to community conflict and gain legitimacy within its host communities. In Akwa Ibom State, ExxonMobil has carried out several CSR activities ranging from road construction to provision of potable water and electricity, environmental protection activities, upgrading of educational and health facilities as well as support to professions and civil society groups. These seem to be good as they have added value to the local communities. However, they are interpreted and perceived from a negative point of view by the host communities. This negative perception is due to fact that the host communities have not been actively involved in the planning of CSR initiatives by the MNCs which to them would have been an avenue to listen and implement those projects that would be directly beneficial to the communities. The host communities feel that the underline reason for such CSR initiatives is profit maximization for the MNCs. The idea of enlightened selfinterest seems to dominate the perceptions of the host communities as every effort made by ExxonMobil is seen as an avenue to increase their earnings, boost their image and their social status rather than protecting the interest of the communities. Emphasis in CSR initiatives needs to shift from just infrastructural facility to issues of capacity building and poverty reduction, which are the main concerns of host communities. Since the host communities are at the receiving end of the MNCs CSR initiatives, it is logical that they should be allowed to give meaningful suggestions on what really meets their needs. As stakeholders in the affairs of the MNC, failure to seek their opinion may continually jeopardize oil exploration and exploitation activities in this regionand this may always result in strained relationship between the host communities and the oil companies.

\section{References}

Abubakri, O. R., Ogodo, G., \& Adedowole, F. I. (2014).Public relations, corporate social responsibility and oil communities in Niger Delta region, Nigeria. New Media and Mass Communication, 26, 35-41.

Afinotan, L. A., \& Ojakorotu, V. (2009). The Niger Delta crisis: Issues, challenges and prospect. African Journal of Political Science and International Relations, 3(5), 191-198.

Ajibade, L. T., \& Awomuti, A. A. (2009). Petroleum exploitation or human exploitation? A overview of Niger Delta oil producing communities in Nigeria. An International Multi-Disciplinary Journal, 3(1), 111-124. http://dx.doi.org/10.4314/afrrev.v3i1.43559

Ako, R., T., Obokoh, L. O., \& Okonmah, P. (2009). Foeging peaceful relationships between oil-companies and host-communities in Nigeria's Delta region. Journal of Enterprising Communities, 3(2), 205-216. http://dx.doi.org/10.1108/17506200910960888

Amao, O. O. (2008). Corporate social responsibility, multinational corporation and the law in Nigeria: Controlling multinationals in host states. Journal of African Law, 54(1), 89-113. http://dx.doi.org/10.1017/s0021855308000041

Ashton-Jones, N. (1998). The human ecosystems of the Niger Delta. Ibadan: KraftBooks.

Blowfield, M., \& Frynas, J. (2005). Setting new agendas: Critical perspective on corporate social responsibility in the developing world. International Affair, 81(3), 499-513. http://dx.doi.org/10.1111/j.14682346.2005.00465.x

Commission Delta Development Commission (NDDC). (2004). Niger Delta Regional Development Master Plan: Draft 3. Directorate of Planning. Port Harcour: NDDC.

Enuoh, R., \& Inyang, B. J. (2014). Effective Management of Corporate Social Responsibility(CSR) for desired outcome: A Niger Delta Issue. International Journal of Business Administration, 5(4), 32-38. http://dx.doi.org/10.5430/ijba.v5n4p32

Evuleocha, S. U. (2005). Managing indigenous relations: Corporate social responsibility in a new age of activism. Corporate Communication, 10(4), 328-340. http://dx.doi.org/10.1108/13563280510630124

Eweje, G. (2006). The role of MNEs in community development initiative in developing countries: Corporate social responsibility at work in Nigeria and Southern Africa. Business and Society, 45(2), 93-129. http://dx.doi.org/10.1177/0007650305285394

Eweje, G. (2007). Multinational oil companies CSR initiatives in Nigeria: The skepticism of stakeholders in host communities. Managerial Law, 49(5/6), 218-235. http://dx.doi.org/10.1108/03090550710841340

Fox, T., Ward, H., \& Howard, B. (2002). Public sector roles in strengthening corporate social responsibility: A baseline study. Washington, DC: World Bank.

Freeman, M. (1998). The social responsibility of business is to increase profit. In L. B. Pincus (Ed.), Perspective in business ethics. Singapore: McGraw Hills. 
Freeman, R. (2004). The stakeholder approach revisited. Zeitschrift fur Wirtschafts- und Unternehmensethik, $5(3), 220-241$.

Frynas, J. G. (2005). The false developmental promise of corporate social responsibility: Evidence multinational oil companies. International Affairs, 81(3), 581-598. http://dx.doi.org/10.1111/j.1468-2346.2005.00470.x

Garriga, E., \& Mele, D. (2004). Corporate social responsibility theories: mapping the territory. Journal of Business Ethics, 52, 51-71. http://dx.doi.org/10.1023/B:BUSI.0000039399.90587.34

Hohen, C. (2007). Corporate social responsibility: An institutional perspective. Academy of Management Journal, 31, 854-872.

Hohnen, P., \& Potts, J. (2007). Corporate social responsibility: An implementation guide for business. International Institute for Sustainable Development.

Ibok, E. E., \& Mboho, K. S. (2011). Corporate social responsibility towards host communities in Nigeria: Focus on ExxonMobil in Akwa Ibom State. Journal of Sociology, Psychology and Anthropology in Practice, 3(1), 110-119.

Idemudia, U. (2007). Community perceptions and expectations: Reinventing the wheels of corporate social responsibility practices in the Nigeria oil industry. Business and Society Review, 112(3), 369-405. http://dx.doi.org/10.1111/j.1467-8594.2007.00301.x

Idemudia, U. (2009). Corporate partnership and community development in the Nigeria oil industry: Strengths and limitations. Retrieved from www.commder/files/1061-files-7pdf

Idemudia, U., \& Ite, U. E. (2006). Corporate-community relations in Nigeria's oil industry. Corporate Social Responsibility and Environment Management, 13, 194-206. http://dx.doi.org/10.1002/csr.101

Inyang, B. J. (2013). Defining the role engagement of small and medium-sized enterprises (SMEs) in corporate social responsibility (CSR). International Business Research, 6(5), 123-132. http://dx.doi.org/10.5539/ibr.v6n5p123

Ite, U. E. (2004). Multinationals and corporate social responsibility in developing countries: A case study of Nigeria. Corporate Social Responsibility and Environment Management, 11, 1-11. http://dx.doi.org/10.1002/csr.49

Mbat, D., Ibok, E., \& Daniel, E. (2013). ExxonMobil and corporate social responsibility in Akwa Ibom State, Nigeria: Past and present. Public Policy and Administration Research, 3(3), 21-28.

Michael, I. C., Min, W. Z., Ling, K. C., \& Kai, D. Y. S. (2015). Proposition of an interactive process approach in exploring the relationship between corporate social responsibility (CSR) strategy and perceived CSR: Case of ExxonMobil in Nigeria's petroleum industry. International Journal of Business and Management, 10(2), 186-195. http://dx.doi.org/10.5539/ijbm.v10n2p186

NIPC. (n.d.). (Oil and Gas industry). Retrieved from http://nipc.gov.ng/index.php/invest-innigeria/opportunities-by-sectors/oil-and-gas.html

Nwesom, C. (2011). Conflict in Niger Delta, more than a local affair. A special report form US Institute for Peace. Washington, DC.

Ojo, G. U. (2012). Community perception and oil companies corporate social responsibility initiative in the Niger Delta. Studies in Sociology of Science, 3(4), 11-21.

Olanrewaju, U. (2014, September 26). Corporate social responsibility of corporations to host communities. Business Day Newspaper. Retrieved from www.businessdayonline/com/2014/09/c0rporate-socilresponsibility-csr-of-corporations-to-host-communities/\#.VZuxOPwo-TK

Orlitzky, M. (2007). Corporate social performance and firm's risk: A meta-analysis review. Business and Society, 40(4), 369-396. http://dx.doi.org/10.1177/000765030104000402

Oteh, C. O., \& Eze, R. C. (2012). Vandalization of oil pipeline in the Niger Delta region of Nigeria and poverty: An overview. Studies of Sociology of Science, 3(2), 13-21.

Saunders, M., Lewis, P., \& Thornhill, A. (2009). Research methods for business students. London: Prentice Hall.

Shell Petroleum Development Company. (2007). Shell annual report 2006. SPCE Nigeria Limited.

Thomas, G., \& Nowak, M. (2006). Corporate social responsibility: A definition (pp. 1-20). Curtin University of Technology. 
Total Upstream Companies in Nigeria. (2011). Total. Abuja.

Tuodolo, F. (2009). Corporate social responsibility: Between civil society and oil industry in the developing world. An International E-Journal for Critical Geographies, 8(3), 530-541.

Udeh, J. (2002). Petroleum revenue management: the Nigerian perspective at oil, gas, mining and chemicals. Department of the WBG and ESMAP. In Workshop on Petroleum Revenue Management (pp. 23-24). Washington D.C.

UNIDO. (2007). What is corporate social responsibility? United Nation Industrial Development Organization. Retrieved from www.unido.org/en.../crs/what-is=crs.htm

WBCSD. (1998). Meeting challenges expectations: Corporate social responsibility (pp. 1-31). World Business Council for Sustainable Development, Netherlands.

WBCSD. (2001). Corporate social responsibility: Making good business sense. World Business Council for Sustainable Development. Retrieved from www.wbcsd.org

Weltweit, B. (2008). Corporate social responsibility across the Middle East and Nort Africa. Retrieved from www.csr.welweit.de/.../finalbackground/pdt

Yin, R. K. (1994). Case study research- design and methods (Applied social research methods series). Newbury Park, CA: Sage.

\section{Copyrights}

Copyright for this article is retained by the author(s), with first publication rights granted to the journal.

This is an open-access article distributed under the terms and conditions of the Creative Commons Attribution license (http://creativecommons.org/licenses/by/3.0/). 